\title{
Corporate social responsibility and firm financial performance: A literature review
}

\author{
Nguyen Thu Thuy Tien ${ }^{1,2, *}$, Nguyen Ha Lien $\mathrm{Chi}^{3}$
}

${ }^{1}$ University of Economics and Law, VNU-HCM, Vietnam

${ }^{2}$ Curtin University of Technology Singapore Campus

${ }^{3}$ University of Foreign Trade - Ho Chi Minh City, Vietnam

\section{Correspondence}

Nguyen Thu Thuy Tien, University of Economics and Law, VNU-HCM, Vietnam

Curtin University of Technology Singapore Campus

Email: tienntt@uel.edu.vn; tien.nguyen@curtin.edu.au

History

- Received: 05/02/2020

- Accepted: 29/06/2020

- Published: 16/08/2020

DOI : 10.32508/stdjelm.v4i3.579

\section{Check for updates}

\section{Copyright}

(c) VNU-HCM Press. This is an openaccess article distributed under the terms of the Creative Commons Attribution 4.0 International license.

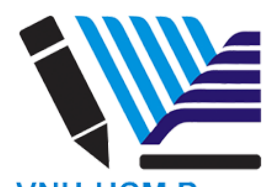

\begin{abstract}
This paper aims to investigate the literature on Corporate Social Responsibility (CSR) to provide a comprehensive overview of whether CSR would make a difference to organisational financial outcomes. The paper also provides a closer focus on CSR research in Vietnam. Through an extensive analysis of 86 most recent empirical studies from 2015 to 2020, we found that the contribution of CSR to firm financial performance has received significant support from the literature. Yet the overall findings are still inconsistent, and the majority of evidence is mainly from developed countries. The current literature on CSR and firm performance highlights some important issues, ranging from theoretical background, CSR measures, methodological issues, the need to consider intervening factors in CSR-firm performance relationship, and the need to extend this literature further in developing and emerging countries. The literature on CSR-firm performance research in Vietnam closely resembles these problems. Research in this country domain is still scarce in both quantity and quality, reflecting in a number of issues including the limited number of international publications, the absence of theory-driven research, and the less rigorous research design. Building on these findings, we recommend future research to (i) adopt the multi-theoretical approach for a more extensive view on whether and how CSR contributes to firm performance; (ii) obtain more rigorous methodological approaches to measure a wide range of CSR dimensions and address the issue of endogeneity in CSR-firm performance causal relationship; (iii) open the Pandora box to explore why and through which channels CSR can improve firm financial performance with the presence of situational factors; and (iv) build the literature with more evidence from different country contexts and from developing and emerging countries.
\end{abstract}

Key words: Corporate Social Responsibility (CSR), Firm financial performance, Literature review, Vietnam

\section{INTRODUCTION}

Over the past few decades, Corporate Social Responsibility (hereinafter CSR) has become a growing topic of interest to organisations, communities, researchers, and policy makers. CSR has been defined in multiple ways. For instance, it was originally portrayed as "the social responsibility of business encompasses the economic, legal, ethical, and discretionary expectations that society has of organisations at a given point in time" $\left[{ }^{1}\right.$, page 500]. In 2011, CSR was redefined by the European Commission as a broader concept focusing more on the responsibility and duty aspect rather than the voluntary acts of organisations. In that sense, CSR is described as "the responsibility of enterprises for their impacts on society" [European Commission 2011, cited in ${ }^{2}$, page 5]. Another definition of CSR is "context-specific organisational actions and policies that take in to account stakeholders' expectations and the triple bottom line of economic, social, and environmental performance" $\left[{ }^{3}\right.$, page 855$]$.
Due to its perceived importance to business and society, Corporate Social Responsibility has become a topic of interest in both research and practice. In modern trends, it is believed that CSR is an essential success factor for organisations and helps to build positive corporate image and reputation in the eyes of consumers and stakeholders, especially with the shift to focus more on the environment and community of the society in recent years ${ }^{4}$. There is a common belief that CSR not only helps companies to improve their reputation, but also brings great economic outcomes. Theoretically, research on the question "Is good ethics good business?", both conceptual and empirical, is not new. A number of studies have reviewed this literature, emphasising that the relationship between CSR and firm financial performance does exist ${ }^{4-7}$. However, it is also highlighted by these studies that up to date, the overall finding of CSR-firm performance relationship is still inconsistent at best. More importantly, empirical reviews on CSR and firm financial performance tend to focus more on evidence from developed countries, leaving this question unanswered 
in the context of developing and emerging markets ${ }^{6}$. Therefore, it is needed to conduct a comprehensive review of CSR and firm financial performance relationship with wider evidence from both developed and developing countries for a more thorough understanding of this literature in different economic and institutional settings.

This paper sets out to provide an overview of the most recent CSR-firm financial performance literature which capture evidence from both developed and developing countries, and with a closer view on CSR research in Vietnam. To achieve this purpose, we applied the common review techniques to generate a sample of empirical and theoretical papers on CSR and firm financial performance from 2015 to 2020 and used this sample as the foundation for our literature review. We structured our study as follow. The paper starts with an overview of our sample, followed by a comprehensive review of empirical evidence on CSR and firm financial performance in the global context and in Vietnam. On this basis, the paper addresses a number of important issues in the current literature, including CSR management approaches, theoretical background, the role of intervening factors, and methodological issues in CSR-firm financial performance relationship. The paper concludes with some implications and directions for future research.

\section{LITERATURE REVIEW}

In this study we adopted the common techniques used in literature review study to generate our data. First, we conducted a wide search for empirical evidence on CSR and firm financial performance on the most common databases, including Web of Science, ProQuest, Science Direct, and Google Scholar with a combination of these key terms: "CSR", "Corporate Social Responsibility", "Firm financial performance", "Firm value". Second, we filtered our search to only include empirical papers that directly address the impact of CSR on firm financial performance and narrowed down our search within 2015-2020 to capture the most recent evidence on this literature. Third, we did not exclude evidence from lower ranked journals, as we aimed to gather more evidence from emerging and developing countries (with the assumption that more studies on CSR-firm financial performance in developing countries are published in these journals). To support our analysis, we also included some discussion papers, case studies and previous literature review papers in our search. Our data collection procedure has resulted in a sample of 93 international publications on CSR and firm financial performance. Of which 86 are empirical studies and 7 are literature review, discussion papers and case studies. We also conducted a search for international publications on CSR in Vietnam following these above steps. We purposely widened the time range and search topics to cover as many studies in this literature as possible. Our search came up with 49 international publications on CSR in Vietnam in total and three publications specifically addressing CSR-firm financial performance relationship.

Table 1 provides a summary of our sample. The list of all empirical studies included in the sample can be found in Appendix 1: Summary of all empirical studies on CSR and firm financial performance). It can be seen that evidence of CSR-firm financial performance relationship is still heavily skewed towards US and developed countries. Evidence from developing and emerging countries, particularly Vietnam, is still limited.

\section{CSR-firm financial performance evidence in a global context}

Table 2 provides an overview of the empirical findings on CSR and firm financial performance relationship. It can be seen that different aspects of firm financial performance have been examined in the literature, including accounting performance ${ }^{8}$, market performance $^{9}$, or both ${ }^{10}$. Some studies also use qualitative measures to capture firm financial performance based on management perceptions ${ }^{11}$.

Empirically, the relationship between CSR and firm financial performance has received strong support from the literature with 61 out of 86 studies confirming the positive impact of CSR on organisational financial outcomes. For instance, CSR is found to increase firm accounting performance ${ }^{12-15}$; market performance $^{16-18}$; or both ${ }^{10,19}$.

However, despite a large number of studies supporting the business case of CSR, overall, this literature is still inconclusive. It is evident that the impact of CSR on firm financial performance is not statistically significant ${ }^{4}$, especially after controlling for endogeneity $^{20}$; or negative ${ }^{21-23}$; or mixed, depending on different dimensions of $\mathrm{CSR}^{24-26}$.

\section{CSR-firm financial performance evidence in Vietnam}

Vietnam is one example of a country that provides a unique cultural and institutional setting that can bring prior relevant CSR theories and findings to the test. The country offers an interesting and promising research domain with its unique political context 


\begin{tabular}{llll}
\hline $\begin{array}{l}\text { Table 1: Summary of international publications addressing the relationship between CSR and firm financial } \\
\text { performance }\end{array}$ & Number of publications & $\begin{array}{l}\text { Country } \\
\text { (research domain) }\end{array}$ & Number of publications \\
\hline Type of paper & 86 & US \& developed countries & 50 \\
Empirical studies & 5 & Developing countries & 33 \\
Literature reviews & 2 & Vietnam & 3 \\
Case study, discussion & 93 & Journal ranking (ABDC & Number of publications \\
Total & Number of publications & ranking system) & 86 \\
Year of publication & 8 & A* \& A & 35 \\
2020 & 19 & & 20 \\
2019 & 16 & C & 19 \\
2018 & 26 & Unranked & \\
2017 & 11 & & \\
2016 & 13 & &
\end{tabular}

Table 2: Evidence on CSR - firm financial performance relationship

$\begin{array}{ll}\text { Financial performance measures } & \text { Number of publications } \\ \text { Accounting performance (ROA, ROE, ROI, ROS, Profitability, Leverage...) } & 25 \\ \text { Market performance (stock return, market to book ratio, Tobin's Q...) } & 27 \\ \text { Both accounting and market performance } & 20 \\ \text { Qualitative performance measure } & 4 \\ \text { CSR - firm financial performance evidence } & \text { Number of publications } \\ \text { Positive impact } & 61 \\ \text { Negative impact } & 4 \\ \text { Mixed impact } & 17 \\ \text { Non-significant impact } & 4\end{array}$

of a socialist and a multi-cultural and ethnic background with a long history of traditions, values, and norms ${ }^{27}$. The transitioning economy of Vietnam has been through rapid development and modernisation. However, along with the rapid changes in the country is the vague and weak legal and governance system, which leads to a growing number of business scandals, misbehaviour, and concerns about social, human rights, and environmental issues. Some highlighted scandals were the case of Vedan dumping untreated wastes to Thi Vai river back in $2008^{28}$, Formosa destroying the sea ecology in Central Coast with their untreated wastes in $2016^{29}$, or VN Pharma importing low standard medicines from questionable sources and being irresponsible to customers in
$2017^{30}$. These examples emphasise the need to raise awareness of CSR and effective CSR governance in Vietnam.

In practice, CSR initiatives had not been actively introduced in the country until 2007 with the establishment of the Global Compact Network Vietnam and the membership to WTO. Up to date, the main CSR actors are still Western MNCs and large corporations. It is criticised that this problem is attributed to (1) the weak legal system, (2) the lack of involvement of important government agencies and industry actors, for instance, Vietnam Chamber of Commerce (VCCI), (3) the high level of corruptions and briberies, and (4) the lack of funding and financial resources. Consequently, these issues have limited the extension of 
CSR practices to a larger scale ${ }^{2}$.

Table 3 provides an overview of CSR literature in Vietnam. Even though this literature remains thin, it shows a good level of diversity. Prior research on CSR in Vietnam has mainly focused on (1) conceptual framework ${ }^{31-33}$, (2) perceptions on $\operatorname{CSR}^{34-36}$, (3) CSR adoption and CSR performance ${ }^{23,37-42}$ with relevance to employee rights, labour standards and industrial actions ${ }^{43-46}$, (4) CSR in MNCs ${ }^{47-50}$, (5) CSR disclosure ${ }^{51,52}$ and governance ${ }^{53}$, (6) government responsiveness and regulatory compliance ${ }^{54}$, and (7) the business case for CSR, which will be discussed in detail below.

\begin{tabular}{ll} 
Table 3: International publications on CSR in Vietnam \\
\hline CSR research topics in Vietnam & $\begin{array}{l}\text { Number of } \\
\text { international } \\
\text { publications }\end{array}$ \\
Conceptual frameworks & 3 \\
CSR perceptions & 3 \\
CSR practices and performance & 11 \\
CSR in MNCs & 4 \\
CSR disclosure, governance, and com- & 4 \\
pliance & 24 \\
The business impact of CSR & 49 \\
Total & \\
CSR - organisational outcomes & 7 \\
Firm efficiency, productivity, employee & 72 \\
behaviour, knowledge sharing & \\
Customer behaviour, supplier rela- & 12 \\
tionship, employer branding & \\
Firm competitiveness and internalisa- \\
tion
\end{tabular}

Though still scarce in quantity, the extant studies focusing on organisational-level consequences of CSR have provided evidence to support the business impact of CSR, such that CSR engagement can bring benefits to organisations in Vietnam, including enhancing employee behaviour ${ }^{55-57}$ and customer behaviour ${ }^{58-65}$, improving firm efficiency ${ }^{66}$, promoting knowledge sharing ${ }^{67,68}$, increasing firm engagement to foreign markets ${ }^{69}$, increasing employees' productivity $^{23}$, increasing supplier performance ${ }^{70}$, improving brand performance and customer service ${ }^{71-73}$, and strengthening organisational competitiveness ${ }^{74}$.
CSR literature in Vietnam also provides some supporting evidence on the positive impact of CSR on firm financial performance, including the studies of Hoang $(2005)^{75}$, Kabir and Thai $(2017)^{76}$, and Xie, Jia $(2017)^{77}$. However, the three notable empirical studies on CSR-firm financial performance in Vietnam either limit their focus only on listed companies, which hinders the generalisability of the results ${ }^{76}$, or face some potential issues with the research design, particularly the cross-sectional data and small sample sizes, which would threaten the reliability of the results ${ }^{75,77}$.

\section{ISSUES AND IMPLICATIONS OF CSR-FIRM FINANCIAL PERFORMANCE LITERATURE}

A review of the literature on CSR-firm financial performance above has implied that there is strong evidence to support the positive impact of CSR on firm financial performance, which is in accordance with previous reviews on this literature ${ }^{5,78-80}$. The sections below will provide a more detailed discussion on the theoretical background, CSR measurement approaches, intervening factors, and methodological approaches used in CSR-firm financial performance, and consequently, identify some important issues and implications for future research.

\section{Theories underlying the business case of CSR}

Table 4 provides an overview of the use of theories in CSR-firm financial performance research. Out of 86 empirical studies, 46 (54\%) used either a single theory or multiple theories to explain the logic behind CSR-firm financial performance relationship. However, theoretical background and assumptions were still absent in almost half of prior empirical research in this sample (40 studies). This is problematic as the lack of theory-driven empirical research in CSRfirm financial performance literature would prevent us from achieving a systematic and precise view of whether, how and why CSR practices can improve firm financial performance. The absence of solid theoretical frameworks might also threaten the rigorousness of the hypothesis development and research design in empirical study settings ${ }^{81}$.

It can also be seen in Table 4 that CSR-firm financial performance empirical research utilises some main theories, including stakeholder theory, slack resource theory, resource-based view, institutional theory, and signalling theory to gauge the relationship between the two. Of which, stakeholder theory ${ }^{82}$ is widely 


\begin{tabular}{ll}
$\begin{array}{l}\text { Table 4: Theories used in CSR-firm financial } \\
\text { performance research }\end{array}$ & $\begin{array}{l}\text { Number of } \\
\text { publications }\end{array}$ \\
\hline Theoretical approach & 34 \\
Single theory & 12 \\
Multiple theories & 40 \\
No theory & 86 \\
Total & Number of \\
publications
\end{tabular}

used in CSR-firm financial performance research and it is also the most popular theoretical foundation for the mainstream research on CSR. Stakeholder theory states that organisations are surrounded by networks of stakeholders - those who either affect or are affected by the decisions made by the organisation. Some important stakeholders include, but not limited to: customers, shareholders, employees, suppliers, communities, and environmentalists ${ }^{82}$. Stakeholders are akin to organisational effectiveness as they can control valuable resources to organisations. As such, organisational success depends on its capacity to manage the relationship with stakeholders, which is the essential tool for value generation ${ }^{78,83-85}$.

Despite being widely used in the literature, the stakeholder theory is heavily criticised for its lack of specificity, vacuousness, and impracticality. It fails to provide a specific framework on how and to what extent organisations should manage their relationship with different stakeholders ${ }^{86}$. As a result, it is recommended that future research on CSR-firm financial performance should build upon a multi-theoretical approach for a more complete and overarching view of this relationship ${ }^{87}$. Yet this line of research is still under-developed with only 12 out of 86 studies representing in the current sample.

\section{CSR measurement approaches}

Table 5 below provides an overview of how CSR is measured. In the wider literature, CSR is measured based on four common approaches, including: (1) corporate disclosure, such as annual reports, public announcements, letters to the shareholders, and other corporate disclosures; (2) reputational ratings - or indexes; (3) social audits - which are the voluntary social programs that lead to desirable social outcomes and (4) managerial principles and values $5,84,88$. Among the above-mentioned approaches to measure CSR, reputational ratings, or indexes, particularly KLD rating, is the most common method, particularly in CSR-firm financial performance research. Besides KLD indexes, some other studies also used similar databases that are also widely used in the literature, for instance, the Dow Jones Sustainability Indexes (DJSI) ${ }^{89}$, or World Bank enterprise database ${ }^{90}$. KLD is the comprehensive database offered by the research firm Kinder, Lydenberg, and Domini (KLD). KLD database has been commonly used in CSR research $^{9,91-93}$ as a well-suited and reliable measurement approach as it covers a wide range of CSR aspects and the database itself is robust. KLD captures 13 different dimensions of CSR and within each dimension it covers both CSR strengths and CSR concerns ${ }^{94-96}$. Among them, community, corporate governance, diversity, employee relations, environment, human rights, and products are the most commonly-used categories to construct CSR ratings. However, even with the same database, different researchers have included a different number of dimensions to build their CSR construct ${ }^{97-99}$. Some studies also added additional dimensions to KLD construct, for instance, customer and supplier relations, media and ethical advertisement, and partnership with NGOs ${ }^{100-102}$.

Beside common dimensions captured by KLD and other indexes, CSR is also measured as internal CSR and external CSR ${ }^{103}$, based on Carroll's CSR pyramid including economic, legal, ethical and discretionary responsibilities ${ }^{104}$, as social recognition reflected in the number of CSR awards ${ }^{105}$, or as a dummy variable to indicate the presence of CSR strategies in organisations ${ }^{106}$.

Overall, it can be learned from the literature that CSR has been measured differently and there is no consensus agreement on (1) how to measure it and (2) what aspect should or should not be included in this construct.

\section{Intervening factors of CSR-firm financial performance relationship}

Table 6 presents the use of mediators and moderators in the CSR-firm financial performance relationship. It can be seen that CSR-firm financial performance relationship is moderated by a wide range of factors, 
Table 5: CSR measurement approaches

\begin{tabular}{|c|c|}
\hline Measurement approaches & $\begin{array}{l}\text { Corporate disclosure } \\
\text { Reputational ratings } \\
\text { Social audits } \\
\text { Managerial philosophy and values }\end{array}$ \\
\hline CSR dimensions & $\begin{array}{l}\text { Environment } \\
\text { Employee relations } \\
\text { Product } \\
\text { Diversity } \\
\text { Human rights } \\
\text { Community } \\
\text { Corporate Governance } \\
\text { Controversial business issues: alcohol, gambling, tobacco, firearms, mil- } \\
\text { itary, nuclear power } \\
\text { Customer and supplier relations } \\
\text { Internal CSR and external CSR } \\
\text { Economic } \\
\text { Legal } \\
\text { Ethical } \\
\text { Discretional } \\
\text { Number of CSR awards } \\
\text { Dummies (0/1) if the firm has CSR strategies }\end{array}$ \\
\hline CSR databases/surveys & $\begin{array}{l}\text { Kinder, Lydenberg, and Domini stats (KLD), Rankins, Vigeo, World } \\
\text { Bank enterprise survey, Kanji Chopra, Bloomberg's index, Dow Jones } \\
\text { Sustainability Indexes (DJSI) }\end{array}$ \\
\hline
\end{tabular}

including both internal factors, for instance, competitive strategy ${ }^{13,16}$, innovativeness capability ${ }^{107}$, or firm risk ${ }^{108}$; and external factors, for instance, competition intensity and market turbulence ${ }^{109}$, or institutional environment ${ }^{77}$. It can also be seen that the impact of CSR on firm financial performance varies in different types of organisations (state-owned or nonstate-owned, MNCs or domestic companies) ${ }^{87,96}$, in different phases during a crisis (pre/post-crisis) ${ }^{17}$, and with different levels of CSR performance (best in class/worst in class) ${ }^{20}$. What can be learned from this literature is that CSR and firm financial performance relationship are likely contextual, and therefore, it is critical for research in this domain to consider possible variables that potentially affect the direction and magnitude of CSR's contribution to firm financial outcomes. However, this line of research is still limited with only 27 out of 86 studies (30\%) examining situational factors in their models. The literature also highlights an important point that research on CSRfirm financial performance has moved further to find explanations of why and how CSR contributes to firm financial performance. On this thought, several studies have identified the channels (mediators) through which CSR translates firm financial outcomes, for instance, marketing competence ${ }^{109}$, innovation ${ }^{106}$, management effectiveness ${ }^{9}$, or competitive advantage $^{14}$. However, this research domain has remained modest with only 20 out of 86 (23\%) studies including mediators in their models.

\section{Methodological approaches in CSR - firm fi- nancial performance research}

Table 7 provides an overview of the research designs used in the most recent empirical studies on CSR and firm financial performance. It is evident that most of the studies used secondary data and panel data to gauge the relationship between CSR and performance and used Ordinary Least Squares (OLS), Generalised Least Squares (GLS) or Partial Least Squares (PLS) approach to analyse such relationship.

Some studies on CSR-firm financial performance relationship have highlighted that endogeneity is an important methodological issue which might threaten the reliability of parameter estimation. Endogeneity refers to the problem where at least one independent variable is correlated with the error term, causing biases in the prediction of parameters in regression models ${ }^{110}$. This problem is mainly caused by three main factors, including (1) omitting variables, which 
Table 6: Intervening factors of CSR-firm financial performance relationship

\begin{tabular}{|c|c|}
\hline Intervening factors & Number of publications \\
\hline Studies with intervening factors & 47 \\
\hline Moderators & 18 \\
\hline Categorical factors & 9 \\
\hline Mediators & 20 \\
\hline Studies without intervening factors & 39 \\
\hline Type of intervening factors & \\
\hline Moderators & $\begin{array}{l}\text { Competitive actions } \\
\text { Competition intensity } \\
\text { Market turbulence } \\
\text { Institutional environment } \\
\text { Market differentiation } \\
\text { Firm visibility } \\
\text { Corporate Strategic Philanthropy } \\
\text { Strategic emphasis } \\
\text { Corporate governance } \\
\text { Foreign investor ownership } \\
\text { Institutional ownership } \\
\text { Block-holders' control power } \\
\text { Outside investment } \\
\text { Firm risk } \\
\text { Discretionary cash } \\
\text { Sale persistence } \\
\text { Firm size } \\
\text { Innovation } \\
\text { Trust } \\
\text { Management efficiency } \\
\text { Marketing capacity }\end{array}$ \\
\hline Categorical factors & $\begin{array}{l}\text { Best in class/worst in class } \\
\text { Pre/post crisis period } \\
\text { Industries } \\
\text { Ownership (State owned/non-state-owned) } \\
\text { Type of organisation (MNEs/domestic firms) }\end{array}$ \\
\hline Mediators & $\begin{array}{l}\text { Competitive advantages } \\
\text { Customer satisfaction } \\
\text { Firm reputation/image } \\
\text { Marketing competence } \\
\text { Innovation } \\
\text { Corporate Governance } \\
\text { Cost of capital } \\
\text { Access to financial capital } \\
\text { Firm risk/risk management } \\
\text { Total-factor performance }\end{array}$ \\
\hline
\end{tabular}


Table 7: Research design in CSR-firm financial performance studies

\begin{tabular}{ll}
\hline Data collection & Number of publications \\
Primary (survey) & 13 \\
Secondary (database) & 73 \\
Data & 33 \\
One-year observation & 53 \\
Panel data & \\
Methodology & 34 \\
OLS/descriptive & 33 \\
Fixed/random GLS/PLS & 5 \\
SEM/path analysis & 14 \\
Instrumental variable approaches & \\
\hline
\end{tabular}

are important factors that might predict firm financial performance but are not included in the model; (2) reverse causality - the phenomenon when CSR can increase firm financial performance, but firm financial performance can also predict $\mathrm{CSR}^{111}$; and (3) measurement error, when the proposed measurement approach does not fully capture $\mathrm{CSR}^{79}$. By default, this problem of endogeneity violates the assumption of the exogenous error term in the OLS regression approach and affects the consistency of parameter estimation under OLS. Consequently, it can be understood that parameter estimation based on the OLS approach is biased with the presence of endogeneity problem.

One of the most common approaches to parameter estimation on panel data is the fixed effect/random effect least square ${ }^{110}$. However, the fixed ef$\mathrm{fect} /$ random least square approach is still prone to bias and inconsistency as (1) it only removes the unobserved time-constant effect but not unobserved timevariant effect ${ }^{112}$. (2) The models after transformation still need to satisfy all the assumptions of OLS ${ }^{110}$. (3) For a panel with short periods $(t<5)$, fixed effect estimation is biased ${ }^{113}$. And (4), fixed effect estimator does not allow observed time-constant variables (e.g. industry dummies, geographic locations) in the model as it cannot distinguish between observed time-constant and unobserved time-constant effects ${ }^{110}$. As such, it is needed for research on CSR and firm financial performance to address the problem of endogeneity by adopting more advanced and complex analytic procedures and tools, for instance, the instrumental variable approach (two stage/three stage least squares (2SLS/3SLS) or System Generalised Method of Moments (System GMM) ${ }^{114}$ ) to build a solid research design that fully addresses endogeneity problem.
The idea of an instrumenting technique is to remove the proportion of the endogenous/predetermined $\mathrm{X}$ that is correlated with the error terms by, firstly, identify truly exogenous instrumental variables $\mathrm{Z}$ which are correlated with $\mathrm{X}$ and indirectly correlated with $\mathrm{Y}$, then remove the part of $\mathrm{X}$ that is correlated with the disturbance term by regressing it against those instrumental variables. Next, the fitted values of $\mathrm{X}$ (conditioning on $\mathrm{Z}$ ), which are now uncorrelated with the error terms, are used in the model with $\mathrm{Y}$, to estimate $\beta^{115}$. The instrumental variables can be external, in the case of 2SLS, or internal using deeper lagged levels (or lagged differences) of the endogenous/predetermined variables, in the case of Anderson-Hsiao's method ${ }^{116}$. As such, correlations between the regressor and the error terms are likely to be removed after the first differencing transformation and instrumental variable techniques. Yet it can be seen from Table 7 that the instrumental variable approach is still not widely used in CSR-firm financial performance research with only 14 out of $86(16 \%)$ empirical studies adopting this approach.

\section{IMPLICATIONS FOR FUTURE RESEARCH}

Overall, the empirical literature on CSR and firm financial performance has provided strong support for this relationship with most studies in our sample confirming the positive impact of CSR on firm financial outcomes. This literature also highlights some important implications for future research.

Firstly, it is critical for CSR-firm financial performance research to build a solid theoretical background and assumptions to explain the relationship between CSR and firm financial performance. The 
absence of theory and the dominance of a singletheoretic approach might be partly responsible for the inconclusiveness of evidence regarding the impact of CSR on firm financial performance ${ }^{117}$. It has been suggested that research needs to go beyond a singletheoretic approach in favour of a multi-theoretic approach that is capable of providing a more comprehensive and nuanced understanding of the wellsprings of the business impact of CSR.

Secondly, it is important to acknowledge that the CSR concept is multi-dimensional in its nature and there is no best way to measure CSR. Even though the KLD index continues to show its popularity and reliability in measuring CSR, it is recommended for future research to take into consideration other dimensions of CSR which are not captured by KLD for a more wellrounded construct.

Thirdly, as the positive impact of CSR and firm financial performance is strongly confirmed, future research should go further to investigate possible intermediate factors and the mechanisms behind this relationship ${ }^{79}$. Future studies focusing on why CSR improves performance with an emphasis on the processes, communication, and decision making within organisations $^{118-120}$ would significantly extend our knowledge in this literature.

Fourthly, a very important implication from CSRfirm financial performance literature is the need for a rigorous research design to reveal the true causality between CSR and firm financial performance ${ }^{79}$. Future studies in this domain need to address endogeneity with more complex analytical approaches and need to take into consideration different aspects of firm financial performance. While accounting measure is a retrospective measure reflecting the internal efficiency of the company's operations and management control, market performance, for instance, Tobin's $\mathrm{Q}$, is a prospective measure indicating the market's perception of the firm's ability to generate profit and shareholder returns in the future ${ }^{121}$. Therefore, it is suggested that future research should use both accounting measures and market measures to reflect two distinct yet complementary aspects of firm financial performance $^{121,122}$.

Lastly, the CSR-firm financial performance literature is inviting more evidence from different national and institutional contexts, particularly in developing and transitioning economies. The literature has pointed out that CSR-firm financial performance relationship is highly contextual. As such, the presence of comparative studies which examine this relationship in different cultural, political, and institutional settings would stand to extend our knowledge in this domain much further.

While prior evidence has been heavily focused on Western countries, research on CSR-firm financial performance in developing countries has become an emerging field of study ${ }^{123}$. Particularly in Vietnam, this literature is still in its infancy. Given the unique national and institutional setting, and a growing concern about CSR engagement in Vietnam, future studies that provide a more comprehensive view of the relationship of CSR and firm financial performance in the Vietnamese context are both warranted and overdue. These studies may also serve to illuminate some specific aspects that have wider significance, as well as offer important points of difference from prior findings.

\section{CONCLUSION}

CSR has become an important factor and linked to various operational results of a company. Due to the rising attention of this topic in both academic and practice, this paper has summarised a number of the most recent empirical studies on the relationship between CSR and firm financial performance and offered a closer look into the CSR literature in the Vietnamese context. It is found that the contribution of CSR on firm financial performance has received strong support from literature, although the overall findings are still inconsistent. It is recommended that future research would probably benefit from the implications on the measurement of CSR, the intervening factors, the problem of endogeneity in research design, and the need to conduct research on CSR and firm financial performance in different cultural and institutional contexts.

This paper is not without limitations. It attempts to provide an extensive review of CSR and firm financial performance literature, however, there are possibilities that some recent studies on CSR-firm performance were not captured in our study. Another limitation is that the review on CSR literature in Vietnam, though similar, might not characterise CSR literature in other emerging, developing, and transitioning economies. Nevertheless, future research might benefit from the implications and suggestions provided by this paper.

\section{APPENDIX}

The list of all empirical studies included in the sample can be found in the Table 8 . 
Table 8: Summary of all empirical studies on CSR and firmfinancial performance

\begin{tabular}{|c|c|c|}
\hline Author(s) & Year & Journal \\
\hline Agan Y, Kuzey C, Acar MF, Acikgoz A & 2016 & Journal of Cleaner Production \\
\hline Agyemang OS, Ansong A & 2017 & Journal of Global Responsibility \\
\hline Akisik, O., \& Gal, G. & 2017 & $\begin{array}{l}\text { Sustainability Accounting, Management and Policy } \\
\text { Journal }\end{array}$ \\
\hline Alikaj A, Nguyen CN, Medina E & 2017 & Journal of Management Development \\
\hline Amini C, Dal Bianco S. & 2017 & $\begin{array}{l}\text { Corporate Governance-the International Journal of } \\
\text { Business in Society }\end{array}$ \\
\hline Anser MK, Zhang Z, Kanwal L. & 2018 & $\begin{array}{l}\text { Corporate Social Responsibility and Environmental } \\
\text { Management }\end{array}$ \\
\hline Ansong A. & 2017 & Cogent Business \& Management \\
\hline $\begin{array}{l}\text { Awaysheh A, Heron RA, Perry T, Wilson } \\
\text { JI. }\end{array}$ & 2020 & Strategic Management Journal \\
\hline Bai X, Chang J. & 2015 & Asia Pacific Journal of Management \\
\hline $\begin{array}{l}\text { Bilbao-Terol A, Arenas-Parra M, Alvarez- } \\
\text { Otero S, Cañal-Fernández V. }\end{array}$ & 2019 & Management Decision \\
\hline $\begin{array}{l}\text { Bocquet R, Le Bas C, Mothe C, Poussing } \\
\text { N. }\end{array}$ & 2017 & Journal of Business Ethics \\
\hline Boonnual C, Prasertsri W, Panmanee P. & 2017 & $\begin{array}{l}\text { Journal of Business and Retail Management Re- } \\
\text { search }\end{array}$ \\
\hline $\begin{array}{l}\text { Cao RQ, Schniederjans DG, Gu VC, } \\
\text { Schniederjans MJ. }\end{array}$ & 2019 & Social Responsibility Journal \\
\hline Chao C-M, Ho C-H. & 2019 & $\begin{array}{l}\text { Review of Integrative Business and Economics Re- } \\
\text { search }\end{array}$ \\
\hline Chen-En H, Wen-Min L, Shiu-Wan H. & 2019 & Annals of Operations Research \\
\hline Cho SY, Lee C. & 2019 & Journal of Business Ethics \\
\hline Choongo P. & 2017 & Sustainability \\
\hline $\begin{array}{l}\text { Cornett MM, Erhemjamts O, Tehranian } \\
\text { H. }\end{array}$ & 2016 & Journal of Banking \& Finance \\
\hline Crifo P, Diaye M-A, Pekovic S. & 2016 & International Journal of Production Economics \\
\hline Devie D, Liman LP, Tarigan J, Ferry J. & 2018 & Social Responsibility Journal \\
\hline Ding DK, Ferreira C, Wongchoti U. & 2016 & International Review of Financial Analysis \\
\hline DiSegni DM, Huly M, Akron S. & 2015 & Social Responsibility Journal \\
\hline Famiyeh S. & 2017 & Social Responsibility Journal \\
\hline Farooq O, Aguenaou S, Amor MA. & 2015 & Journal of Applied Business Research \\
\hline Feng M, Wang X, Kreuze JG. & 2017 & American Journal of Business \\
\hline Gangi F, Mustilli M, Varrone N. & 2019 & Journal of Knowledge Management \\
\hline $\begin{array}{l}\text { Giannarakis G, Konteos G, Zafeiriou E, } \\
\text { Partalidou X. }\end{array}$ & 2016 & Investment Management \& Financial Innovations \\
\hline Gregory A, Tharyan R, Whittaker J. & 2015 & Journal of Business Ethics \\
\hline Habaragoda BS. & 2018 & $\begin{array}{l}\text { International Journal of Information, Business and } \\
\text { Management }\end{array}$ \\
\hline $\begin{array}{l}\text { Hafiz YA, Rizwan Qaiser D, Muhammad } \\
\text { AuH. }\end{array}$ & 2020 & $\begin{array}{l}\text { Corporate Social Responsibility and Environmental } \\
\text { Management }\end{array}$ \\
\hline Harjoto M, Laksmana I & 2018 & Journal of Business Ethics \\
\hline Hasan I, Kobeissi N, Liu L, Wang H. & 2018 & Journal of Business Ethics \\
\hline Hoang LC. & 2015 & Academy of Marketing Studies Journal \\
\hline Hou TCT. & 2019 & $\begin{array}{l}\text { Corporate Social - Responsibility and Environmen- } \\
\text { tal Management }\end{array}$ \\
\hline
\end{tabular}




\begin{tabular}{|c|c|c|}
\hline Table 8 continued & & \\
\hline $\begin{array}{l}\text { Huynh Anh Thu T, Hwang YS, Yu C, Yoo } \\
\text { SJ. }\end{array}$ & 2018 & Sustainability \\
\hline Janamrung B, Issarawornrawanich P. & 2015 & Social Responsibility Journal \\
\hline Jia X. & 2020 & $\begin{array}{l}\text { Corporate Social Responsibility and Environmental } \\
\text { Management }\end{array}$ \\
\hline Joseph Dery N, Ibrahim M, Sare YA. & 2018 & Journal of Global Responsibility \\
\hline Kabir R, Thai HM & 2017 & Pacific Accounting Review \\
\hline Kang C, Germann F, Grewal R. & 2016 & Journal of Marketing \\
\hline Kao EH, Yeh C-C, Wang L-H, Fung H-G. & 2018 & Pacific-Basin Finance Journal \\
\hline Kiessling T, Isaksson L, Yasar B. & 2016 & Journal of Business Ethics \\
\hline Kim K-H, Kim M, Qian C. & 2018 & Journal of Management \\
\hline Kim M-S, Thapa B. & 2018 & Sustainability \\
\hline $\begin{array}{l}\text { Laguir I, Marais M, El Baz J, Stekelorum } \\
\text { R. }\end{array}$ & 2018 & Management Decision \\
\hline Laskar N, Maji SG. & 2017 & IPE Journal of Management \\
\hline Lee S, Jung H. & 2016 & Management Decision \\
\hline Lin L, Pi-Hsia H, De-Wai C, Lai CW. & 2019 & Asia Pacific Management Review \\
\hline Lloyd R. & 2017 & $\begin{array}{l}\text { Corporate Social Responsibility and Environmental } \\
\text { Management }\end{array}$ \\
\hline Long W, Li S, Wu H, Song X. & 2020 & $\begin{array}{l}\text { Corporate Social Responsibility and Environmental } \\
\text { Management }\end{array}$ \\
\hline Mahmood CK, Malik QA. & 2018 & $\begin{array}{l}\text { NUML International Journal of Business \& Man- } \\
\text { agement }\end{array}$ \\
\hline Mangantar M. & 2019 & European Research Studies \\
\hline $\begin{array}{l}\text { Martinez-Conesa I, Soto-Acosta P, } \\
\text { Palacios-Manzano M. }\end{array}$ & 2017 & Journal of Cleaner Production \\
\hline $\begin{array}{l}\text { Masum MH, Uddin MM, Ahmed H, Ud- } \\
\text { din MH. }\end{array}$ & 2019 & Academy of Strategic Management Journal \\
\hline Miller SR, Eden L, Li D. & 2018 & Journal of Business Ethics \\
\hline Mishra D. & 2017 & Journal of Business Ethics \\
\hline Nakamura E. & 2015 & Journal of Global Responsibility \\
\hline Oh H, Bae J, Kim S-J. & 2017 & Journal of Business Ethics \\
\hline Park S. & 2017 & Social Responsibility Journal \\
\hline Park Y, Park Y, Hong PC, Yang S. & 2017 & Benchmarking-an International Journal \\
\hline Ting PH, Yin Hy. & 2018 & $\begin{array}{l}\text { Corporate Social Responsibility and Environmental } \\
\text { Management }\end{array}$ \\
\hline Price JM, Sun W. & 2017 & Journal of Business Responsibility \\
\hline Quere BP, Nouyrigat G, Baker CR. & 2018 & Journal of Business Ethics \\
\hline QuyVo T, Phung Le V. & 2016 & Industrial Engineering and Management Systems \\
\hline $\begin{array}{l}\text { Saeidi SP, Sofian S, Saeidi P, Saeidi SP, } \\
\text { Saaeidi SA. }\end{array}$ & 2015 & Journal of Business Responsibility \\
\hline Schons L, Steinmeier M. & 2016 & $\begin{array}{l}\text { Corporate Social Responsibility and Environmental } \\
\text { Management }\end{array}$ \\
\hline Sekhon AK, Kathuria LM. & 2019 & Corporate Governance \\
\hline Sledge S. & 2015 & Academy of Strategic Management Journal \\
\hline Story J, Neves P. & 2015 & Business Ethics: A European Review \\
\hline Sun L, Yu TR. & 2015 & Review of Accounting and Finance \\
\hline Sun W, Yao S, Govind R. & 2019 & Journal of Business Ethics \\
\hline Taghian M, D’Souza C, Polonsky M. & 2015 & Social Responsibility Journal \\
\hline
\end{tabular}




\begin{tabular}{|c|c|c|}
\hline Table 8 continued & & \\
\hline Tahira N, Shahzad F, Ghazanfar Ali A, Ijaz & 2020 & Corporate Social Responsibility and Environmental \\
\hline Ur R, Nawaz F & & Management \\
\hline $\begin{array}{l}\text { Tarigan J, Hatane SE, Linneke S, Widjaja } \\
\text { DC. }\end{array}$ & 2019 & Investment Management \& Financial Innovations \\
\hline $\begin{array}{l}\text { Titisari KH, Moeljadi M, Kusuma R, In- } \\
\text { drawati NK. }\end{array}$ & 2019 & Investment Management \& Financial Innovations \\
\hline Usman U, Usman FI. & 2017 & $\begin{array}{l}\text { International Journal of Management Research and } \\
\text { Reviews }\end{array}$ \\
\hline Walker K, Zhang Z, Na N. & 2019 & British Journal of Management \\
\hline Walker K, Zhang Z, Yu B. & 2016 & European Business Review \\
\hline $\begin{array}{l}\text { Wang W, Xue-Zhou Z, Feng-Wen C, Wu } \\
\text { C-H, Tsai S, Wang J. }\end{array}$ & 2019 & $\begin{array}{l}\text { International Journal of Environmental Research } \\
\text { and Public Health }\end{array}$ \\
\hline $\begin{array}{l}\text { Wang DH-M, Chen P-H, Yu TH-K, Hsiao } \\
\text { C-Y. }\end{array}$ & 2015 & Journal of Business Responsibility \\
\hline Wang Q, Dou J, Jia S & 2016 & Business \& Society \\
\hline Wiengarten F, Lo CK, Lam JY. & 2017 & Journal of Business Ethics \\
\hline $\begin{array}{l}\text { Woon Leong L, Siong Hook L, Azman- } \\
\text { Saini WNW. }\end{array}$ & 2020 & $\begin{array}{l}\text { Corporate Social Responsibility and Environmental } \\
\text { Management }\end{array}$ \\
\hline Xie X, Jia Y, Meng X, Li C. & 2017 & Journal of Cleaner Production \\
\hline Youn H, Hua N, Lee S. & 2015 & International Journal of Hospitality Management \\
\hline
\end{tabular}




\section{ABBREVIATIONS}

2SLS/3SLS: Two/Three Stage Least Squares

CSR: Corporate Social Responsibility

DJSI: Dow Jones Sustainability Indexes

GLS: Generalised Least Squares

GMM: Generalised Method of Moments

KLD: Kinder, Lydenberg, and Domini

MNC: Multi-National Corporations

NGO: Non-Governmental Organisation

OLS: Ordinary Least Squares

PLS: Partial Least Squares

ROA: Return on Assets

ROE: Return on Equity

ROI: Return on Investment

ROS: Return on Sales

VCCI: Vietnam Chamber of Commerce Institute

WTO: World Trade Organisation

\section{CONFLICT OF INTEREST}

The authors declare that there are no conflict of interest in the publication of this study.

\section{AUTHORS' CONTRIBUTION}

Nguyen Thu Thuy Tien: search on databases, data input, write-up.

Nguyen Ha Lien Chi: data input, write up, proof-read.

\section{REFERENCES}

1. Carroll AB. A Three-Dimensional Conceptual Model of Corporate Performance. Academy of Management Review. 1979;4(4):497-505. Available from: https://doi.org/10.5465/ amr.1979.4498296.

2. Hamm B. Corporate social responsibility in Vietnam: Integration or merely adaptation? Parcific News. 2012;p. 4-8.

3. Aguinis $\mathrm{H}$. Organizational responsibility: Doing good and doing well. In: Zedeck S, editor. APA handbook of industrial and organizational psychology 3 Washington, DC: American Psychological Association. 2011;p. 855-879. Available from: https://doi.org/10.1037/12171-024.

4. Malik M. Value-Enhancing Capabilities of CSR: A Brief Review of Contemporary Literature. Journal of Business Ethics. 2015;127(2):419-438. Available from: https://doi.org/10. 1007/s10551-014-2051-9.

5. Beurden P, Gossling T. The Worth of Values - A Literature Review on the Relation Between Corporate Social and Financial Performance. Journal of Business Ethics. 2008;82(2):407424. Available from: https://doi.org/10.1007/s10551-0089894-x.

6. Goyal P, Rahman Z, Kazmi A. Corporate sustainability performance and firm performance research: Literature review and future research agenda. Management Decision. 2013;51(2):361-379. Available from: https://doi.org/10.1108/ 00251741311301867.

7. Das L, Bhunia A. The Impact of CSR on Firms' Financial Performance-A Literature Review. American Journal of Business, Economics and Management. 2016;4(4):66.

8. Chen-En H, Wen-Min L, Shiu-Wan H. Does CSR matter? Influence of corporate social responsibility on corporate performance in the creative industry. Annals of Operations Research. 2019;278(1-2):255-279. Available from: https://doi. org/10.1007/s10479-017-2626-9.
9. Kang C, Germann F, Grewal R. Washing Away Your Sins? Corporate Social Responsibility, Corporate Social Irresponsibility, and Firm Performance. Journal of Marketing. 2016;80(2):59-79. Available from: https://doi.org/10.1509/ jm.15.0324.

10. Cornett MM, Erhemjamts O, Tehranian H. Greed or good deeds: An examination of the relation between corporate social responsibility and the financial performance of U.S. commercial banks around the financial crisis. Journal of Banking \& Finance. 2016;70:137-159. Available from: https: //doi.org/10.1016/j.jbankfin.2016.04.024.

11. Martinez-Conesa I, Soto-Acosta P, Palacios-Manzano M. Corporate social responsibility and its effect on innovation and firm performance: An empirical research in SMEs. Journal of Cleaner Production. 2017;142:2374-2383. Available from: https://doi.org/10.1016/j.jclepro.2016.11.038.

12. Ansong A. Corporate social responsibility and firm performance of Ghanaian SMEs: The role of stakeholder engagement. Cogent Business \& Management. 2017;4(1). Available from: https://doi.org/10.1080/23311975.2017.1333704.

13. Lee $\mathrm{S}$, Jung $\mathrm{H}$. The effects of corporate social responsibility on profitability The moderating roles of differentiation and outside investment. Management Decision. 2016;54(6):1383-1406. Available from: https://doi.org/10. 1108/MD-07-2015-0268.

14. Saeidi SP, Sofian S, Saeidi P, Saeidi SP, Saaeidi SA. How does corporate social responsibility contribute to firm financial performance? The mediating role of competitive advantage, reputation, and customer satisfaction. J Bus Res. 2015;68(2):341-350. Available from: https://doi.org/10.1016/ j.jbusres.2014.06.024.

15. Wiengarten F, Lo CKY, Lam JYK. How does Sustainability Leadership Affect Firm Performance? The Choices Associated with Appointing a Chief Officer of Corporate Social Responsibility". Journal of Business Ethics. 2017;140(3):477493. Available from: https://doi.org/10.1007/s10551-0152666-5.

16. Kim KH, Kim M, Qian C. Effects of Corporate Social Responsibility on Corporate Financial Performance: A Competitive-Action Perspective. Journal of Management. 2018;44(3):1097-1118. Available from: https://doi.org/10. 1177/0149206315602530.

17. Lins KV, Servaes H, Tamayo A. Social Capital, Trust, and Firm Performance: The Value of Corporate Social Responsibility during the Financial Crisis. Journal of Finance. 2017;72(4):1785-1823. Available from: https://doi.org/10. 1111/jofi.12505.

18. Price JM, Sun W. Doing good and doing bad: The impact of corporate social responsibility and irresponsibility on firm performance. J Bus Res. 2017;80:82-97. Available from: https://doi.org/10.1016/j.jbusres.2017.07.007.

19. Walker K, Zhang Z, Yu B. The angel-halo effect How in creases in corporate social responsibility and irresponsibility relate to firm performance. European Business Review. 2016;28(6):709-722. Available from: https://doi.org/10.1108/ EBR-11-2015-0139.

20. Awaysheh A, Heron RA, Perry T, Wilson Jl. On the relation between corporate social responsibility and financial performance. Strategic Management Journal. 2020;41(6):965-987. Available from: https://doi.org/10.1002/smj.3122.

21. Oh H, Bae J, Kim SJ. Can Sinful Firms Benefit from Advertising Their CSR Efforts? Adverse Effect of Advertising Sinful Firms' CSR Engagements on Firm Performance. Journal of Business Ethics. 2017;143(4):643-663. Available from: https://doi.org/ 10.1007/s10551-016-3072-3.

22. Quere BP, Nouyrigat G, Baker CR. A Bi-Directional Examination of the Relationship Between Corporate Social Responsibility Ratings and Company Financial Performance in the European Context. Journal of Business Ethics. 2018;148(3):527544. Available from: https://doi.org/10.1007/s10551-0152998-1. 
23. Wrana J, Diez JR. Multinational enterprises or the quality of regional institutions-What drives the diffusion of global CSR certificates in a transition economy? Evidence from Vietnam. Journal of Cleaner Production. 2018;186:168-179. Available from: https://doi.org/10.1016/j.jclepro.2018.03.113.

24. Janamrung B, Issarawornrawanich P. The association between corporate social responsibility index and performance of firms in industrial products and resources industries: empirical evidence from Thailand. Social Responsibility Journal. 2015;11(4):893. Available from: https://doi.org/ 10.1108/SRJ-11-2013-0141.

25. Ting $\mathrm{PH}$, Yin $\mathrm{H}$. How do corporate social responsibility activities affect performance? The role of excess control right. Corporate Social - Responsibility and Environmental Management. 2018;25(6):1320-1331. Available from: https://doi.org/ $10.1002 /$ csr. 1641 .

26. Sekhon AK, Kathuria LM. Analyzing the impact of corporate social responsibility on corporate financial performance: evidence from top Indian firms. Corporate Governance. 2019;19(1):143-157. Available from: https://doi.org/10.1108/ CG-04-2019-0135.

27. Vuong QH. Vietnam's political economy in transition (19862016). 2014;.

28. Thanh P. Phá hoại môi trường: Công ty Vedan Việt Nam sẽ bị xử lý mức cao nhất. 16/09/2008. Dân trí. 2008;.

29. Ortmann S. Environmental governance in Vietnam: Institutional reforms and failures:. Springer. 2017;Available from: https://doi.org/10.1007/978-3-319-49760-0.

30. Le-Phuong. Thuốc chữa ung thư giả của VN Pharma bị chặn trước khi ra thị trường. VNExpress 24/08/2017. 2017;

31. Nguyen M, Bensemann J, Kelly S. Corporate social responsibility (CSR) in Vietnam: a conceptual framework. International Journal of Corporate Social Responsibility. 2018;3(1):9. Available from: https://doi.org/10.1186/s40991-018-0032-5.

32. Nguyen M, Truong M. The Effect of Culture on Enterprise's Perception of Corporate Social Responsibility: The Case of Vietnam. Procedia CIRP. 2016;;40:680-686. Available from: https://doi.org/10.1016/j.procir.2016.01.154.

33. Hoang $D$, Jones B. Why do corporate codes of conduct fail? Women workers and clothing supply chains in Vietnam. Global Social Policy. 2012;12(1):67-85. Available from: https://doi.org/10.1177/1468018111431757.

34. My N, Minh T. The Effect of Culture on Enterprise's Perception of Corporate Social Responsibility: The Case of Vietnam. In: Seliger G, Kohl H, Mallon J, editors. 13th Global Conference on Sustainable Manufacturing - Decoupling Growth from Resource Use. Procedia CIRP;402016:680-686.

35. Huang YF, Manh-Hoang D, Kumar V. Consumers' perception on corporate social responsibility: Evidence from Vietnam. Corporate Social Responsibility and Environmental Management. 2019;26(6):1272-1284. Available from: https: //doi.org/10.1002/csr.1746.

36. QuyVo T, Phung LV. Consumers' Perception towards Corporate Social Responsibility and Repurchase Intention: A Study of Consumer Industry in Vietnam. Industrial Engineering and Management Systems. 2016;15(2):173-180. Available from: https://doi.org/10.7232/iems.2016.15.2.173

37. Nayak R, Akbari M, Far SM. Recent sustainable trends in Vietnam's fashion supply chain. Journal of Cleaner Production. 2019;225:291-303. Available from: https://doi.org/10.1016/j. jclepro.2019.03.239.

38. Anh NQ, Hens L. Environmental performance of the cement industry in Vietnam: the influence of ISO 14001 certification. Journal of Cleaner Production. 2015;96:362-378. Available from: https://doi.org/10.1016/j.jclepro.2013.09.032.

39. Nhi N, Boruff B, Tonts M. Fool's Gold: Understanding Social, Economic and Environmental Impacts from Gold Mining in Quang Nam Province, Vietnam. Sustainability. 2018;10(5). Available from: https://doi.org/10.3390/su10051355.

40. Ni B, Tamechika H, Otsuki T, Honda K. Does ISO14001 raise firms' awareness of environmental protection? The case of Vietnam. Environment and Development Economics.
2019;24(1):47-66. Available from: https://doi.org/10.1017/ S1355770X18000396.

41. Tencati A, Russo A, Quaglia V. Sustainability along the global supply chain: the case of Vietnam. Social Responsibility Journal. 2010;6(1):91. Available from: https://doi.org/10.1108/ 17471111011024577.

42. Angie NT, Jeppesen S. SMEs in their Own Right: The Views of Managers and Workers in Vietnamese Textiles, Garment, and Footwear Companies. Journal of Business Ethics. 2016;137(3):589-608. Available from: https://doi.org/10. 1007/s10551-015-2572-x.

43. Anner M. Corporate Social Responsibility and Freedom of Association Rights: The Precarious Quest for Legitimacy and Control in Global Supply Chains. Politics \& Society. 2012;40(4):609-644. Available from: https://doi.org/10.1177/ 0032329212460983.

44. Anner M. CSR Participation Committees, Wildcat Strikes and the Sourcing Squeeze in Global Supply Chains. British Journal of Industrial Relations. 2018;56(1):75-98. Available from: https://doi.org/10.1111/bjir.12275.

45. Hoang D. Labour Standards in the Global Supply Chain: Workers' Agency and Reciprocal Exchange Perspective. Societies. 2019;9(2). Available from: https://doi.org/10.3390/ soc9020038.

46. Brown G. Hansae Vietnam's garment factory: Latest example of how corporate social responsibility has failed to protect workers. Journal of Occupational and Environmental Hygiene. 2017;14(8):D130-D5. Available from: https://doi. org/10.1080/15459624.2017.1296239.

47. Bilowol J, Doan MA. Multinational corporations' role in developing Vietnam's public relations industry through corporate social responsibility. Public Relations Review. 2015;41(5):825-832. Available from: https://doi.org/10.1016/ j.pubrev.2015.06.004.

48. Kim C, Kim J, Marshall R, Afzali H. Stakeholder influence, institutional duality, and CSR involvement of MNC subsidiaries. Bus Res. 2018;91:40-47. Available from: https://doi.org/10. 1016/j.jbusres.2018.05.044.

49. Munro V, Arli D, Rundle-Thiele S. CSR engagement and values in a pre-emerging and emerging country context. International Journal of Emerging Markets. 2018;13(5):12511272. Available from: https://doi.org/10.1108/IJoEM-042018-0163.

50. Tien NH, Anh HDB. Gaining competitive advantage from CSR policy change - Case of foreign corporations in Vietnam. Polish Journal of Management Studies. 2018;18(1):403-417. Available from: https://doi.org/10.17512/pjms.2018.18.1.30.

51. Trang $\mathrm{CH}$, Abeysekera I, Ma S. Board Diversity and Corporate Social Disclosure: Evidence from Vietnam. Journal of Business Ethics. 2018;151(3):833-852. Available from: https: //doi.org/10.1007/s10551-016-3260-1.

52. Trang CH, Abeysekera I, Ma S. Earnings Quality and Corporate Social Disclosure: The Moderating Role of State and Foreign Ownership in Vietnamese Listed Firms. Emerging Markets Finance and Trade. 2019;55(2):272-288. Available from: https://doi.org/10.1080/1540496X.2018.1521801.

53. Tuan LT. Corporate social responsibility, ethics, and corporate governance. Social Responsibility Journal. 2012;8(4):547. Available from: https://doi.org/10.1108/ 17471111211272110 .

54. Malesky E, Taussig M. The danger of not listening to firms: Government responsiveness and the goal of regulatory compliance. Academy of Management Journal. 2017;;60(5):1741-1770. Available from: https://doi.org/10. 5465/amj.2015.0722.

55. Luu TT, Rowley C. From value-based human resource practices to i-deals: software companies in Vietnam. Personnel Review. 2015;44(1):39-68. Available from: https://doi.org/10. 1108/PR-08-2013-0151.

56. Luu TT. Organizational Ambidexterity, Entrepreneurial Orientation, and I-Deals: The Moderating Role of CSR. Jour- 
nal of Business Ethics. 2016;135(1):145-159. Available from: https://doi.org/10.1007/s10551-014-2476-1.

57. Tuan TL. CSR and organizational citizenship behavior for the environment in hotel industry The moderating roles of corporate entrepreneurship and employee attachment style. International Journal of Contemporary Hospitality Management. 2017;29(11):2867-2900. Available from: https://doi. org/10.1108/IJCHM-02-2016-0080.

58. Hang LM, Diem, Ferguson DL. Customer Relationship Enhancements from Corporate Social Responsibility Activities Within the Hospitality Sector: Empirical Research from Vietnam. Corporate Reputation Review. 2016;19(3):244-262. Available from: https://doi.org/10.1057/s41299-016-0001-4.

59. Dung PH, Nam HN. Retaining online customers: Information quality as a sign of corporate social responsibility. International Journal of Business and Society. 2019;20(2):482-500.

60. Hoang PD. Role of Corporate Social Responsibility in Managing Customer Loyalty: An Empirical Study in Vietnam Retailing Industry. In: Lee JW, Pham HHT, Youn MK, editors. 2017 International Conference on Business and Economics. International Conference of the Korea Distribution Science Association. 2017;p. 187-190.

61. Luu TT. How HR flexibility contributes to customer value co-creation behavior. Marketing Intelligence \& Planning. 2016;34(5):646-670. Available from: https://doi.org/10.1108/ MIP-09-2015-0186.

62. Trong TL. CSR and Customer Value Co-creation Behavior: The Moderation Mechanisms of Servant Leadership and Relationship Marketing Orientation. Journal of Business Ethics. 2019;155(2):379-398. Available from: https://doi.org/10. 1007/s10551-017-3493-7.

63. Tuan LT, Rajendran D, Rowley C, Dinh Cong K. Customer value co-creation in the business-to-business tourism context: The roles of corporate social responsibility and customer empowering behaviors. Journal of Hospitality and Tourism Management. 2019;39:137-149. Available from: https://doi.org/10.1016/j.jhtm.2019.04.002.

64. Huynh ATT, Hwang YS, Yu C, Yoo SJ. The Effect of Destination Social Responsibility on Tourists' Satisfaction: The Mediating Role of Emotions. Sustainability. 2018;10(9). Available from: https://doi.org/10.3390/su10093044.

65. Ha TMV, Hartmann M, Langen N. Rewarding the good and penalizing the bad? Consumers' reaction to food retailers' conduct. British Food Journal. 2018;120(11):2539-2553. Available from: https://doi.org/10.1108/BFJ-06-2017-0339.

66. Newman C, Rand J, Tarp F, Trifkovic N. Corporate social responsibility in a competitive business environment. WIDER Working Paper. 2016;Available from: https://doi.org/ 10.35188/UNU-WIDER/2016/050-8.

67. Luu TT. How servant leadership nurtures knowledge sharing The mediating role of public service motivation. International Journal of Public Sector Management. 2016;29(1):91-108. ;Available from: https://doi.org/10.1108/IJPSM-06-2015-0112.

68. Tuan TL. Psychological contract and knowledge sharing CSR as an antecedent and entrepreneurial orientation as a moderator. Corporate Communications. 2016;21(1):2-19. Available from: https://doi.org/10.1108/CCIJ-09-2014-0058.

69. Newman C, Rand J, Tarp F, Trifkovic N. The transmission of socially responsible behaviour through international trade. European Economic Review. 2018;101:250-267. Available from: https://doi.org/10.1016/j.euroecorev.2017.10.013.

70. Lee S-Y. Responsible supply chain management in the Asian context: the effects on relationship commitment and supplier performance. Asia Pacific Business Review. 2016;22(2):325-342. Available from: https://doi.org/10.1080/ 13602381.2015.1070012.

71. Luu TT. Behind brand performance. Asia-Pacific Journal of Business Administration. 2012;4(1):42-57. Available from: https://doi.org/10.1108/17574321211207962.

72. Luu Trong T. Corporate social responsibility, leadership, and brand equity in healthcare service. Social Responsibility
Journal ;8(3):-+ . 2012;8(3):347. Available from: https://doi. org/10.1108/17471111211247929.

73. Luu T, Le V, Masli E, Rajendran D. Corporate social responsibility, ambidextrous leadership, and service excellence. Marketing Intelligence \& Planning. 2019;37(5):580-594. Available from: https://doi.org/10.1108/MIP-05-2018-0157.

74. Thang QN, Nguyen TL, Thanh-Lam N. Impacts of corporate social responsibility on the competitiveness of tourist enterprises: An empirical case of Ben Tre, Vietnam. Tourism Economics. 2019;25(4):539-568. Available from: https://doi.org/ $10.1177 / 1354816618805318$

75. Hoang LC. The impact of market orientation and corporate social responsibility on firm performance: Evidence from Vietnam. Academy of Marketing Studies Journal. 2015;19(1):265-277.

76. Kabir R, Thai HM. Does corporate governance shape the relationship between corporate social responsibility and financial performance? . Pacific Accounting Review. 2017;29(2):227-258. Available from: https://doi.org/10.1108/ PAR-10-2016-0091.

77. Xie X, Jia Y, Meng X, Li C. Corporate social responsibility, customer satisfaction, and financial performance: The moderating effect of the institutional environment in two transition economies. Journal of Cleaner Production. 2017;150:26-39. Available from: https://doi.org/10.1016/j.jclepro.2017.02.192.

78. Carroll $A B$, Shabana KM. The business case for corporate social responsibility: A review of concepts, research and practice. International journal of management reviews. 2010;12(1):85-105. Available from: https://doi.org/10.1111/ j.1468-2370.2009.00275.x.

79. Aguinis H, Glavas A. What We Know and Don't Know About Corporate Social Responsibility: A Review and Research Agenda. Journal of Management. 2012;38(4):932-968. Available from: https://doi.org/10.1177/0149206311436079.

80. Yu-Cheng L, Padliansyah R, Lin T-C. The relationship and development trend of corporate social responsibility (CSR) literature. Management Decision. 2019;58(4):601-624. Available from: https://doi.org/10.1108/MD-10-2018-1090.

81. Taneja SS, Taneja PK, Gupta RK. Researches in Corporate Social Responsibility: A Review of Shifting Focus, Paradigms, and Methodologies. Journal of Business Ethics. 2011;101(3):343-364. Available from: https://doi.org/10. 1007/s10551-010-0732-6.

82. Freeman RE. Strategic management: A stakeholder approach: Cambridge university press. 2010;Available from: https://doi.org/10.1017/CBO9781139192675.

83. Donaldson T, Preston LE. The stakeholder theory of the corporation: Concepts, evidence, and implications. Academy of Management Review. 1995;20(1):65-91. Available from: https://doi.org/10.5465/amr.1995.9503271992.

84. Orlitzky M, Schmidt FL, Rynes SL. Corporate social and financial performance: A meta-analysis. Organization studies. 2003;24(3):403-441. Available from: https://doi.org/10.1177/ 0170840603024003910.

85. Clarkson MBE. A stakeholder framework for analyzing and evaluating corpora. Academy of Management The Academy of Management Review. 1995;20(1):92. Available from: https: //doi.org/10.5465/amr.1995.9503271994.

86. Ambler T, Wilson A. Problems of Stakeholder Theory. Business Ethics: A European Review. 2006;4:30-35. Available from: https://doi.org/10.1111/j.1467-8608.1995.tb00107.x.

87. Kao EH, Yeh C-C, Wang L-H, Fung H-G. The relationship between CSR and performance: Evidence in China. PacificBasin Finance Journal. 2018;51:155-170. Available from: https://doi.org/10.1016/j.pacfin.2018.04.006.

88. Le T, Velencei J, editors. Literature review: the impact of corporate social responsibilty on firm performance. MEB' 18 Proceedings. 2018;.

89. Wang DHM, Chen PH, Yu THK, Hsiao CY. The effects of corporate social responsibility on brand equity and firm performance. J Bus Res. 2015;68(11):2232-2236. Available from: 
https://doi.org/10.1016/j.jbusres.2015.06.003.

90. Amini C, Dal BS. Corporate social responsibility and Latin American firm performance. Corporate Governance-the International Journal of Business in Society. 2017;17(3):403445. Available from: https://doi.org/10.1108/CG-03-20160060 .

91. Waddock SA, Graves SB. The corporate social performancefinancial performance link. Strategic management journal. 1997;18(4):303-319. Available from: https://doi.org/10.1002/(SICI)1097-0266(199704)18:4<303:: AID-SMJ869>3.0.CO;2-G

92. McWilliams A, Siegel D. Corporate social responsibility and financial performance: Correlation or misspecification? . Strategic Management Journal. 2000;21(5):603-609. Available from: https://doi.org/10.1002/(SICI)1097-0266(200005) 21:5<603::AID-SMJ101>3.0.CO;2-3.

93. Kotchen $M$, Moon JJ. Corporate social responsibility for irresponsibility. The BE Journal of Economic Analysis \& Policy. 2012;12(1). Available from: https://doi.org/10.1515/19351682.3308 .

94. Tahira N, Shahzad F, Ghazanfar Ali A, ljaz Ur R, Nawaz F. Corporate social responsibility engagement and firm performance in Asia Pacific: The role of enterprise risk management. Corporate Social - Responsibility and Environmental Management. 2020;27(2):501-513. Available from: https: //doi.org/10.1002/csr.1815.

95. Famiyeh S. Corporate social responsibility and firm's performance: empirical evidence. Social Responsibility Journal. 2017;Available from: https://doi.org/10.1108/SRJ-04-20160049.

96. Alikaj A, Nguyen CN, Medina E. Differentiating the impact of CSR strengths and concerns on firm performance An investigation of MNEs and US domestic firms. Journal of Management Development. 2017;36(3):401-409. Available from: https://doi.org/10.1108/JMD-04-2016-0058.

97. Feng $M$, Wang $X$, Kreuze JG. Corporate social responsibility and firm financial performance Comparison analyses across industries and CSR categories. American Journal of Business. 2017;32(3-4):106-133. Available from: https://doi.org/ 10.1108/AJB-05-2016-0015.

98. Joseph DN, Ibrahim M, Sare YA. Corporate social responsibility and financial performance nexus. Journal of Global Responsibility. 2018;9(3):301-328. Available from: https://doi. org/10.1108/JGR-01-2018-0004.

99. Devie D, Liman LP, Tarigan J, Ferry J. Corporate social responsibility, financial performance and risk in Indonesian natural resources industry. Social Responsibility Journal. 2018;16(1):73-90. Available from: https://doi.org/10.1108/ SRJ-06-2018-0155.

100. Agan Y, Kuzey C, Acar MF, Acikgoz A. The relationships between corporate social responsibility, environmental supplier development, and firm performance. Journal of Cleaner Production. 2016;112:1872-1881. Available from: https:// doi.org/10.1016/j.jclepro.2014.08.090.

101. Agyemang OS, Ansong A. Corporate social responsibility and firm performance of Ghanaian SMEs Mediating role of access to capital and firm reputation. Journal of Global Responsibility. 2017;8(1):47-62. Available from: https://doi.org/10.1108/ JGR-03-2016-0007.

102. Anser MK, Zhang Z, Kanwal L. Moderating effect of innovation on corporate social responsibility and firm performance in realm of sustainable development. Corporate Social Responsibility and Environmental Management. 2018;25(5):799-806. Available from: https://doi.org/10.1002/ csr. 1495 .

103. Habaragoda BS. Corporate Social Responsibility and firm performance: Impact of internal and external CSR on financial performance. International Journal of Information, Business and Management. 2018;10(3):156-170.

104. Hafiz YA, Rizwan Qaiser D, Muhammad AuH. How corporate social responsibility boosts firm financial performance: The mediating role of corporate image and customer satisfaction. Corporate Social - Responsibility and Environmental Management. 2020;27(1):166-177. Available from: https: //doi.org/10.1002/csr.1781.

105. Hou TCT. The relationship between corporate social responsibility and sustainable financial performance: firm-level evidence from Taiwan. Corporate Social - Responsibility and Environmental Management. 2019;26(1):19-28. Available from: https://doi.org/10.1002/csr.1647.

106. Bocquet R, Le Bas C, Mothe C, Poussing N. CSR, Innovation, and Firm Performance in Sluggish Growth Contexts: A Firm-Level Empirical Analysis. Journal of Business Ethics. 2017;146(1):241-254. Available from: https://doi.org/10. 1007/s10551-015-2959-8.

107. Luo X, Bhattacharya CB. Corporate social responsibility, customer satisfaction, and market value. Journal of Marketing. 2006;70(4):1-18. Available from: https://doi.org/10.1509/ jmkg.70.4.001.

108. Hasan I, Kobeissi N, Liu L, Wang H. Corporate Social Responsibility and Firm Financial Performance: The Mediating Role of Productivity: JBE JBE. Journal of Business Ethics. 2018;149(3):671-688. Available from: https://doi.org/10. 1007/s10551-016-3066-1.

109. Bai X, Chang J. Corporate social responsibility and firm performance: The mediating role of marketing competence and the moderating role of market environment. Asia Pacific Journal of Management. 2015;32(2):505-530. Available from: https://doi.org/10.1007/s10490-015-9409-0.

110. Wooldridge JM. Econometric analysis of cross section and panel data: MIT press. 2010;.

111. Erhemjamts O, Li Q, Venkateswaran A. Corporate Social Responsibility and Its Impact on Firms' Investment Policy, Organizational Structure, and Performance. Journal of Business Ethics. 2013;118(2):395-412. Available from: https://doi.org/ 10.1007/s10551-012-1594-x.

112. Bond SR. Dynamic panel data models: a guide to micro data methods and practice. Portuguese economic journal. 2002;1(2):141-162. Available from: https://doi.org/10.1007/ s10258-002-0009-9.

113. Baltagi B. Econometric analysis of panel data: John Wiley \& Sons. 2008;

114. Arellano $\mathrm{M}$, Bover $\mathrm{O}$. Another look at the instrumental variable estimation of error-components models. Journal of econometrics. 1995;68(1):29-51. Available from: https://doi. org/10.1016/0304-4076(94)01642-D.

115. Baum $C F$, Schaffer $M E$, Stillman S. Instrumental variables and GMM: Estimation and testing. Stata journal. 2003;3(1):1-31. Available from: https://doi.org/10.1177/ 1536867 X0300300101.

116. Anderson TW, Hsiao C. Estimation of dynamic models with error components. Journal of the American statistical Association. 1981;76(375):598-606. Available from: https://doi. org/10.1080/01621459.1981.10477691.

117. Frynas JG, Yamahaki C. Corporate social responsibility: Review and roadmap of theoretical perspectives. Business Ethics: A European Review. 2016;25(3):258-285. Available from: https://doi.org/10.1111/beer.12115.

118. Basu K, Palazzo G. Corporate social responsibility: A process model of sensemaking. Academy of management review. 2008;33(1):122-136. Available from: https://doi.org/10.5465/ amr.2008.27745504.

119. Lane AB, Devin B. Operationalizing stakeholder engagement in CSR: A process approach. Corporate Social Responsibility and Environmental Management. 2018;25(3):267-280. Available from: https://doi.org/10.1002/csr.1460.

120. Kim S. The process model of corporate social responsibility (CSR) communication: CSR communication and its relationship with consumers' CSR knowledge, trust, and corporate reputation perception. Journal of Business Ethics. 2019;154(4):1143-1159. Available from: https://doi.org/10. 1007/s10551-017-3433-6. 
121. Salinger MA. Tobin's q, unionization, and the concentrationprofits relationship. The Rand Journal of Economics. 1984;15(2):159-170. Available from: https://doi.org/10.2307/ 2555673

122. Gentry RJ, Shen W. The relationship between accounting and market measures of firm financial performance: How strong is it? Journal of managerial issues. 2010;p. 514-530.

123. Jamali D, Karam C. Corporate social responsibility in developing countries as an emerging field of study. International Journal of Management Reviews. 2018;20(1):32-61. Available from: https://doi.org/10.1111/ijmr.12112. 


\title{
Tổng quan lý thuyết về trách nhiệm xã hội và hiệu quả tài chính của doanh nghiệp
}

\author{
Nguyễn Thu Thủy Tiên ${ }^{1,2, *}$, Nguyễn Hạ Liên $\mathrm{Chi}^{3}$
}

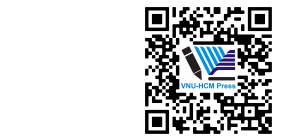

Use your smartphone to scan this QR code and download this article

${ }^{1}$ Trường Đại học Kinh tế - Luạt, ĐHQG-HCM, Việt Nam

${ }^{2}$ Trường Đại học Kỹ thuật Curtin - Cơ sở Singapore

${ }^{3}$ Truơong Đại học Ngoại Thuiong- Cơ sở TPHCM, Việt Nam

Liên hệ

Nguyễn Thu Thủy Tiên, Trường Đại học Kinh tế - Luật, ĐHQG-HCM, Việt Nam

Trường Đại học Kỹ thuật Curtin - Cơ sở

Singapore

Email: tienntt@uel.edu.vn;

tien.nguyen@curtin.edu.au

Lịch sử

- Ngày nhận: 05-02-2020

- Ngày chấp nhận: 29-6-2020

- Ngày đăng: 16-8-2020

DOI : 10.32508/stdjelm.v4i3.579

\section{Check for updates}

\section{Bản quyền}

(c) ĐHQG Tp.HCM. Đây là bài báo công bố mở được phát hành theo các điều khoản của the Creative Commons Attribution 4.0 International license.

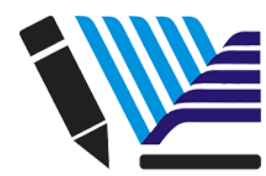

VNU-HCM Press

\section{TÓM TẮT}

Mục tiêu của bài viết này là điều tra tổng hợp những nghiên cứu về mối quan hệ giữa Trách nhiệm xã hôi của doanh nghiệp (CSR) và hiệu quả hoạt động kinh doanh nhằm đưa ra đánh giá toàn diện vê việc liệu Trách nhiệm xã hội có tạo ra sự khác biệt đối với hiệu quả tài chính của doanh nghiệp hay không. Bài viết này còn cung cấp một cái nhìn sâu hơn vào lĩnh vực nghiên cứu này ở Việt Nam. Dựa trên phân tích tổng hợp trên 86 bài nghiên cứu thực nghiệm mới nhất trong lĩnh vực này từ năm 2015 đến năm 2020, chúng tôi tìm thấy nhiểu bằng chứng to lớn chứng minh cho sự đóng góp của CSR vào hiệu quả hoạt động kinh doanh. Tuy nhiên, kết quả tổng quát hóa cho mối quan hệ này vẫn còn chưa thống nhất và phần lớn bằng chứng cho mối quan hệ này đến từ các nước phát triển. Lĩnh vực nghiên cứu mối quan hệ giữa CSR và hiệu quả hoạt động kinh doanh của doanh nghiệp đã nêu ra một số vấn đề quan trọng, từ nền tảng lý thuyết, việc đo lường CSR, các vấn đề về phương pháp nghiên cứu, sự cần thiết phải bao gồm các yếu tố tương tác và các biến trung gian trong mối quan hệ giữa CSR và hiệu quả kinh doanh, và sự cần thiết phải mở rộng lĩnh vực nghiên cứu này hơn nữa ở các nước đang phát triển. Tại Việt Nam, lĩnh vực nghiên cứu này cũng gặp phải các vấn đề tương tự. Nghiên cứu về CSR tại Việt Nam vẫn còn hạn chế và manh mún cả về mặt số lượng lẫn chất lượng, phản ánh qua một số vấn đề như số lượng công bố quốc tế hạn chế, sự thiếu vắng các nghiên cứu dựa trên nền tảng lý thuyết, và sự thiếu chặt chẽ trong cách thiết kế mô hình nghiên cứu. Trên cơ sở những phân tích này, chúng tôi đề xuất đến các nghiên cứu trong tương lai cần phải (i) áp dụng phương pháp đa lý thuyết để cung cấp cái nhìn toàn diện hơn vể mối quan hệ giữa CSR và hiệu quả kinh doanh; (ii) sử dụng phương pháp nghiên cứu chặt chẽ hơn để đo lường nhiêu khía cạnh của CSR và để giải quyết vấn đề nội sinh trong mối quan hệ nhân quả giữa CSR và hiệu quả kinh doanh của doanh nghiệp; (iii) mở ra chiếc hộp Pandora để tìm hiểu sâu hơn vì sao và thông qua những kênh nào CSR có thể gia tăng hiệu quả kinh doanh, và (iv) xây dựng lĩnh vực nghiên cứu này với nhiều bằng chứng hơn từ nhiều quốc gia khác nhau, đặc biệt là từ các quốc gia đang phát triển.

Từ khoá: Trách nhiệm xã hội của doanh nghiệp (CSR), hiệu quả hoạt động tài chính, Nghiên cứu tổng quan, Việt Nam
Trích dẫn bài báo này: Tiên N T T, Chi N H L. Tổng quan lý thuyết về trách nhiệm xã hội và hiệu quả tài chính của doanh nghiệp. Sci. Tech. Dev. J. - Eco. Law Manag.; 4(3):833-850. 